\title{
Integration of Young People into the Latvian Labour Market
}

\author{
Liva Grinevica ${ }^{1}$, Raimonds Kovalevs ${ }^{1},{ }^{1}$ Latvia University of Agriculture
}

\begin{abstract}
The research deals with the question of how different resources affect the labour market integration of the long-term unemployed youth. The main hypothesis it advances is that the youth who have access to different resources will find more stable jobs or develop their own business after unemployment than those lacking such different kinds of support.

In making the education and employment decisions during the transition from school to work, there is strong evidence of the importance for young people to make good initial career decisions and an enduring effect of academic achievement on labour market and education outcomes.

This research is based on scientific discussion of different author opinions and survey results of young people as well as on views on the future vision of authors.
\end{abstract}

Keywords - Labour market, youth integration, youth longterm unemployment.

\section{INTRODUCTION}

Youth unemployment has been a central focus of research on transitions with a significant number of studies focusing on cross-national differences in unemployment levels as well as on the impact of active labour market policies designed to facilitate employment access (Blanchflower, Freeman, 2000).

According to the European Commission Social Agenda of Youth Employment, over 13\% of European Union (EU) youth is not in employment, training or education. The youth unemployment rate is more than twice as high as the rate for adults $(23.6 \%$ in comparison to $9.5 \%$, in November 2013) (European Commission, 2010).

7.5 million persons in the age group 15-24 are neither in employment nor in education or training (NEETs). In 2012, $13.1 \%$ of youth were NEETs, which is 2.2 percentage points more than four years earlier, representing an increase of more than 20\% (Youth Employment, 2014).

According to „The World Development Report 2013” prepared by the World Bank, about 200 million people cannot find work, and one third of them is younger than 25 (The World Development Report, 2013).

Economists' interest in the causes of youth unemployment dates back a long time, with systematic research on the youth labour market, starting at the beginning of the 1980s. The analysis of youth unemployment generally differs according to the explanatory factors considered, the country panel and the time horizon analysed, as well as the regression techniques chosen (Blanchflower, Freeman, 2000). Some of the main explanatory variables considered include changes in the state of the economy, changes in relative population sizes of young people and prime-age persons, labour market institutions, as well as education and training systems.
The authors consider that one of the possibilities to deal with the youth long-term unemployment problem is to encourage youth entrepreneurship and self-employment. It is understood, that only one part of young people is interested in entrepreneurship and are linking future with that. For making a competitive environment for entrepreneurship it is one of the main goals of government to deal with. The authors find that there is no sufficient support for entrepreneurship in Latvia because there are too many criteria to meet if you want to get financial support for a new business idea.

The research focuses on youth interest in business support programmes and on the awareness of them. However, young unemployed people are informed of business support programmes and the possibility to get funding for starting a business. Most of them are interested in self-employment and would like to start a business in different sectors. As the authors found out, the most popular sectors for entrepreneurship in youth's opinion were the tourism sector, finance and accounting, agriculture, manufacturing and services.

The objective of the research is to determine the current youth unemployment trends in the labour market of Latvia and to develop recommendations on how to enhance the quality of education and training to ensure youth employment and social inclusion.

The hypothesis of the research - the youth who have access to different resources will find more stable jobs or make their own business after unemployment than those who lack such different kinds of support.

The research aim is to examine the situation and problems in the youth labour market in Latvia and to identify the alternatives for improving the situation.

The tasks of the research:

- To analyse the theoretical basis of youth's long term unemployment and integration into the labour market;

- To identify the alternatives for improving youth unemployment.

Research methods: the monographic and descriptive methods, analysis and synthesis, the graphic method, statistical analysis and the analysis of youth survey results were applied for fulfilment of the aim and tasks.

\section{THEORETICAL FRAMEWORK OF YOUTH'S INTEGRATION INTO THE LABOUR MARKET}

Since joining the European Union, Latvia has experienced sharp changes in economic development.

Between 2008 and 2012, the rate of long-term unemployment in the European countries increased most significantly for young people without education and work experience (Grinevica, Rivza, 2014). 
In the European Union, young people are, according to Eurostat statistics, one-fifth of the total population. Even if modern Europe offers unprecedented opportunities for young people, they face challenges (aggravated by the economic crisis) related to the education and training systems and to labour market access (Balan, 2014).

According to foreign scientists (Salvador and LeinerKillinger, 2008; Bell and Blanchflower, 2009) engaged in the analysis of the process of youth integration into the labour market, their position on it, which is similar to all other population groups, depends primarily on the general economic situation.

However, young people in search of their first job, including students, encounter many more problems than the unemployed (Berthelot, 1995). Thus young people are forced into the category of long-term unemployed. Moreover, young unemployed people may be condemned to long-lasting depression should they fail to turn their theoretical knowledge into practical ability, gain skills, and improve their professional competence (Sileika et al., 2004).

Employment is an important part of social activity, securing an economic foundation for the existence of the individual and simultaneously predetermining the social status of that individual. Integration into the labour market is successful provided that the differences between youth and adult employment are eliminated, while the rights, duties and possibilities offered to young people within the labour market are the same as those for adult employees. The integration is deemed to succeed in cases where youth employment does not differ from that of adults, when the possibilities offered to young people, within the labour market, are identical to those of adults, any young people have no impact on material and social life, as well as on the public standing of a young person (Sileika et al., 2004).

Youth unemployment is of particular concern as people who become unemployed during their early working years may become demoralised, and people who fail to find a job after leaving full-time education may see depreciation in their human capital and deterioration in their employment prospects, which could lead to social exclusion. At the same time, youth unemployment is problematic not only for those affected, but also for the economy as a whole (Salvador, Leiner-Killinger, 2008).

Integration of young people into the labour market is an issue of critically high priority in the entire European Union (EU) and in Latvia, too. Education and training, as well as the first job experience for young people are considered to be crucial to start their employment career (Buligina et al., 2014).

Getting off to a good start facilitates youth integration into the world of work and lays the foundation for a good career, while it can be difficult to catch up after an initial failure (Sonnet, 2010). The public administrations need to seek solutions at both national and regional level in order to address the problem in a systemic manner (Bubany, Hansen, 2011).

De Koning and Kluve, in their studies analyzed the efficiency of unemployment programmes.

According to De Koning in a comprehensive review of active labour market programmes (covering 130 studies - with most of the training programmes targeted at young people), the author finds that for training programmes "the number of studies that point to positive effects is more or less the same as the number of studies showing insignificant or significantly negative effects" (De Koning, 2005).

Kluve reaches similar conclusions in the review of 95 studies covering 137 programmes (of which a quarter was programmes targeting the young unemployed). Of the 70 training programmes within these, 38 have positive impacts while 32 have zero or negative impacts. He concludes that the training programmes seem to have relatively small effects at best, and often have a significant employment impact only in the longer run (Kluve, 2006).

According to the European Commission, the European Social Fund has for some time been the European Union's main tool to equip young people for the world of work. The fund backs programmes and projects promoting structural reforms which open-up access to training that give the skills and confidence they need to enter the jobs market and thrive in the world of work (Investing in People: EU Funding for Employment and Social Inclusion, 2014).

The authors thought that it was clear that without financial support of the European Social Fund, the unemployed would not get possibility to participate in unemployment programmes and to improve their professional skills.

Changes in youth unemployment are usually closely related to changes in prime-age unemployment, which can be taken as a proxy for variations in the state of the economy. Youth unemployment tends to be more cyclically sensitive than prime-age unemployment, with youth unemployment tending to increase more than prime-age unemployment during periods of recession and to decline more quickly during economic upswings (Abel-Latif, Staneva, 2013).

Youth unemployment problems are a phenomenon that cannot be resolvable in easily, there are needs for financial support from institutions such as financial institutions (for example, the Investment Development Agency of Latvia, Altum (Latvian Development Financial institution), European Social Fund and etc.

Women, young people with disabilities and youth from a migrant background are particularly exposed to the risks of unemployment, long-term unemployment, early school leaving or inactivity (Youth Employment, 2014).

Sileika, Rupsys, Gruzevskis (2004), found that most of studies tend to find aggregate economic activity to be a major determinant of the level of youth unemployment. The central requirements of today's economic and technological development boost the significance of labour force qualifications and provide a strong impetus for the intensification of social development. It should be noted that the efficient use of the labour force in our global society predetermines the competitiveness of the product and encourages social development. In this context, youth unemployment is a particularly undesirable phenomenon, reducing the efficiency of youth labour force within the level of general labour, raising social costs, and restricting social development. The position of young people on the labour market depends on a number of social, economic and demographic factors, leading to the conclusion that youth unemployment as a socio-economic phenomenon is a particularly negative result of the interaction between these factors (Sileika et al., 2004). 
Youth integration into the labour market is affected by a number of factors, including the development of services and manufacturing, education, work motivation, health, sources of household income, standard of living, minority, social life, etc.

Successful youth integration into the labour market is very important for their future options. The success of integration into the labour market is also equal to social inclusion. The authors consider that for the national institutions and government, it is important to draw more attention to youth's integration into the labour market and into society. It also has a significant impact on the country's revenues and development.

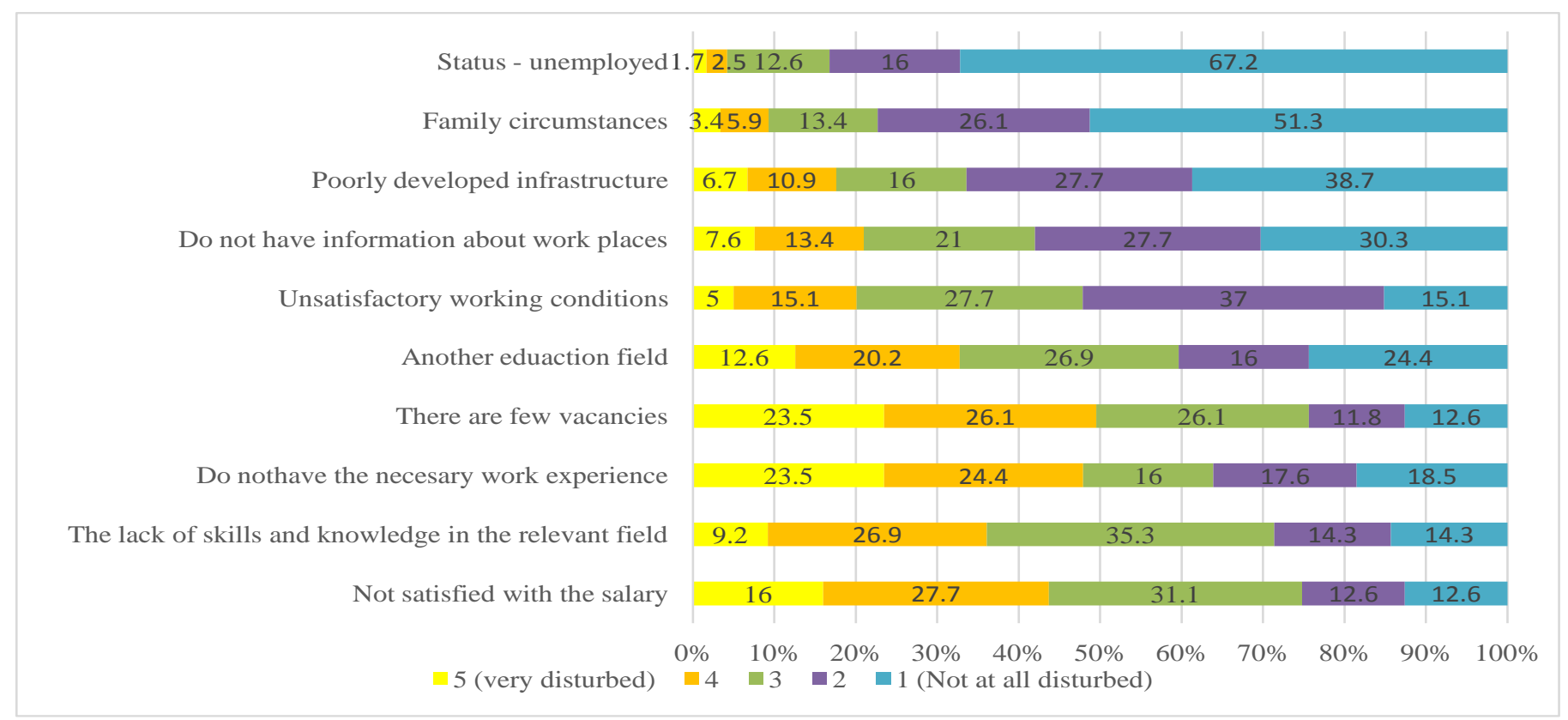

Source: authors' survey results

Fig. 1. Answers to the question: "Please rate, how significant are the following external factors, that disturbed/ hindered you to find a job previously?"

\section{YOUTH EXPERIENCE IN THE LABOUR MARKET AND INTEREST IN ENTREPRENEURSHIP}

According to the previous research that focused on youth's interest in business support programmes and on the awareness of them, the authors made a survey of youth integration into the labour market and identified the main factors that young people are confronted with when they are looking for work. Also the authors paid attention to youth's knowledge about business support tools and programmes. Most of the young people are interested in self-employment and would like to start a business in different sectors. As the authors found out, the most popular sectors for entrepreneurship in youth's opinion were the tourism sector, finance and accounting, agriculture, manufacturing and services.

The authors made a survey $(n=144)$ of young people aged 17 to 30 in Riga region, Latvia. The survey was conducted from September to October 2014. Approximately $20 \%$ of all respondents were male and $80 \%$ were female; taking into account the difference between the respondents' gender, the authors were aware of the fact that the largest proportion of students were female. There will follow a descriptive analysis about young people's opinions of the labour market, of their last work experience and their opinion of the possibility to be self-employed or an entrepreneur.

According to the survey results, $59.5 \%$ of the respondents answered positively to the question "Are you thinking of starting your own business of being self-employed?", $22 \%$ answered negatively, but $11.7 \%$ were not interested in entrepreneurship. $6.8 \%$ gave a different answer, for example, that they were an entrepreneur already and some of them did not have a business idea.

The authors consider that according to Fig. 1 the statement "status - unemployed" did not hinder young people to find a job, $67.2 \%$ of all the respondents $(n=144)$ answered that this factor was not significant. The statements "There are few vacancies" and "Do not have the necessary work experience" were evaluated by $23.5 \%$ as a very troublesome statement. $37 \%$ of the respondents noted that they were not disturbed by "Unsatisfactory working conditions", but $27.7 \%$ of them emphasized that they were partially satisfied with working conditions; based on those opinions, the authors consider that the employers can ensure normal working conditions for young people. $16 \%$ of the respondents marked answer 5 ("very disturbed") and they were not satisfied with their salary which was one of the reasons why they praised the job offer. $27.7 \%$ of all young respondents marked answer 4 ("disturbed") to the statement - "Not satisfied with the salary". $26.9 \%$ noted that they were satisfied rather than dissatisfied with the statement "The lack of skills and knowledge in the relevant field" and $35.3 \%$ of them were partially satisfied with this statement. The authors identified that the statement "knowledge in the relevant field" was not so disturbing that it could cause dissatisfaction with work.

The authors compared the results of the research with the State Employment Agency's European Social Fund project "The Labour Market Studies" in $2006(n=602)$. In 2006 the statements, which did not disturb the young people at all were "family circumstances" and "status - unemployed". But $28 \%$ 
of all the respondents were not satisfied with their salary, $28 \%$ did not have the necessary work experience which was the main reason why they could not be involved into the labour market; $32 \%$ had another education field than job offers in the labour market and also $31 \%$ of the respondents did not have skills and knowledge in the relevant field, but in 2014 only $9.2 \%$ of all the respondents were faced by this problem. In $2006,25 \%$ of all the respondents were partially satisfied with their working conditions, but in 2014 it was $27.7 \%$, and $37 \%$ were satisfied rather than dissatisfied. It means that the technological development also has improved working conditions.

As it is known from Latvia's National Development Plan 2014 - 2020, the main way how to deal with youth unemployment is to direct them to be self-employed. To understand the youth's opinion and knowledge and their interest in business support programmes, the authors analysed the answers to the following question: "Of which business support programmes for business start-ups you have been informed before?" The survey results in Fig. 2 clearly indicate that all of the mentioned statements for youth entrepreneurship are important. Very important factors are tax relief for young entrepreneurs $(63.4 \%)$ and financing opportunities without collateral $(54.5 \%)$. Also, as important factors, young people noted the European Social Fund Courses (46.9\%) and the attraction of Business Angels (46.9\%), but they were not identified as significant factors. The possibility to participate in working groups $(53.8 \%)$ was more important than the availability of Business Incubators (47.6\%), which is surprising, because Business Incubators are a business support instrument where young people can get support in accounting, record keeping, office places and help with business development, as well as have discussions with other young entrepreneurs and get other social support. The authors think that it may be explained by youth's incomplete knowledge of Business Incubator functions. Therefore, the authors believe that for young people, it is important to get information about business environment, development and activities from the universities, where are they studying, e.g. the University of Latvia; the business incubator is established for their students.

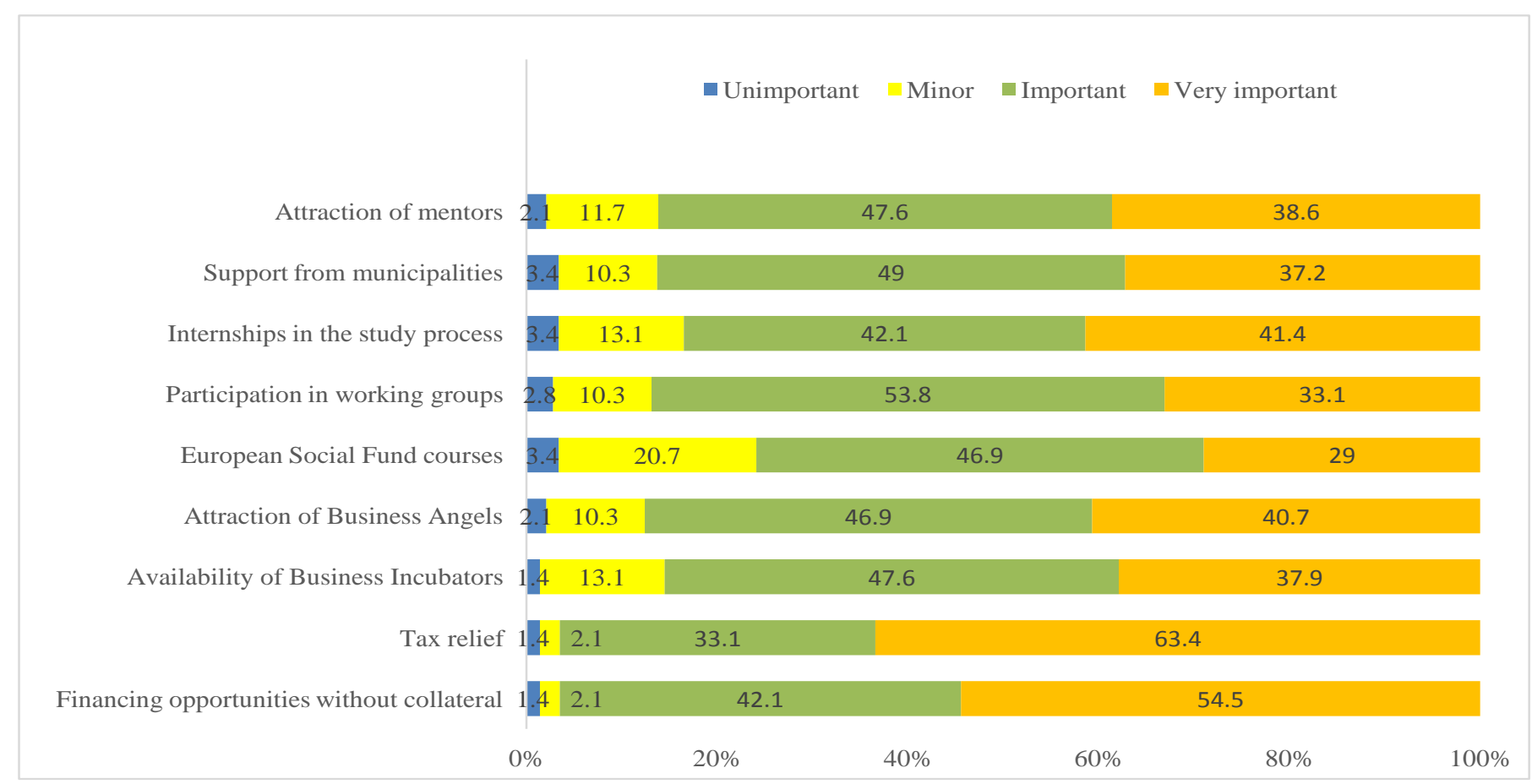

Source: authors' survey results

Fig. 2. Answers to the question: "Of which business support programmes for business start-ups you have been informed before?"

\section{CONCLUSION AND RECOMMENDATIONS}

The first job experience as well as education, training and practical skills are considered to be a crucial precondition for young people to start their employment career and provide future possibilities for their development and social status in society.

The government should promote youth entrepreneurship and self-employment by providing responsive conditions, such as tax remission for young entrepreneurs, contact information and availability of potential partners, customers and financial supporters, provided by the business platform.

At the government level, there is a need to focus on the increase of the minimum wage because in rural areas and small towns the employment opportunities are limited, but in many cases the offered wage would be sufficient only for transport expenses. The financial support from the state in the sectors where the labour force is insufficient has to be offered the state should ensure at least partially subsidized placements for young people; then entrepreneurs will pay more attention to youth employment. In order to tackle the youth unemployment, it is necessary to make them more competitive in the labour market.

Education authorities should ensure close co-operation with employers to understand what kind of skills and knowledge young people are looking for. Through understanding the expectations of employers, the educational institutions need to improve their training programmes by developing young 
people's skills and knowledge that may be necessary for the employer. In practice, an individual can get an idea of future career opportunities and it is important that this is not just a formality, which is widespread today. The close cooperation between educational institutions and the labour market players will promote young people's integration into the labour market.

According to the survey results, presently the most effective scenario for improving the situation in the youth labour market is the one providing the financial support and business instruments for self-employment and small entrepreneurship.

\section{ACKNOWLEDGEMENT}

The preparation of the paper was supported by the National Research Program 5.2. Economic Transformation, Smart Growth, Governance and Legal Framework for the State and Society for Sustainable Development - a New Approach to the Creation of a Sustainable Learning Community, Project EKOSOC_LV.

\section{REFERENCES}

Abel-Latif H., Staneva A. (2013). Does Youth Unemployment Challenge Okun's law in the UK? Swansea University, Department of Economics.

Balan M. (2014). Youth Labour Market Vulnerabilities: Characteristics, Dimensions and Costs. Volume 8, 66-72.

Bell D., Blanchflower D. (2009). What should be done about Rising Unemployment in the UK?, Institute for the Study of Labour, IZA Discussion Paper No. 4040, 1-105.

Berthelot Y. (1995). European and General Global Issues Influencing Employment and Unemployment. Global Employment: An International Investigation into Future Work, United Nations University Press, 30-41.

Blanchflower D. G., Freeman R. B. (2000). Youth Employment and Joblessness in Advanced Countries. University of Chicago Press, 1-492. http://dx.doi.org/10.7208/chicago/9780226056845.001.0001

Bubany S. T., Hansen J. I. C. (2011) Birth Cohort Change in the Vocational Interests of Female and Male College Students, Journal of Vocational Behaviour, Vol. 78, 59-67. http://dx.doi.org/10.1016/j.jvb.2010.08.002

Buligina, I., Putans, R., Sloka, B. (2014). Coherence of Work Based Learning and Regional Development in Latvia. Ekonomika un uznēmējdarbib, 25, 19-26. http://dx.doi.org/10.7250/eb.2014.003

De Koning J. (2005). Active Labour Market Policies: Relevance, Expenditure and Effectiveness. Rotterdam: SEOR Working Paper, 1-29.
Working together for Europe's Young People. A Call to Action on Youth Unemployment (2010). European Commission, Brussels, COM(2013) 447 final, 1-22.

Grinevica L., Rivza B. (2014) Integration of Young People into the Labour Market through Participation in Business Support Programmes. Economic Science for Rural development. Integration and Sustainable Development. No. 36, 86-95.

Investing in People: EU Funding for Employment and Social Inclusion. (2014). Social Europe Guide. Volume 7, European Commission, Directorate- General for Employment, Social Affairs and Inclusion, $1-96$.

Jauniešu bezdarbnieku kvalitatīvā sastāva atbilstības darba tirgus pieprasījumam izvērtēšana. (2006). Eiropas Sociālā fonda programmas "Darba tirgus pētījumi" Projekts "Nodarbinātības valsts aǵentūras pētījumi", 1-127.

Kluve, J. (2006). The Effectiveness of European Active Labour Market Policy, IZA Discussion Paper No. 2018; RWI Discussion Paper No. 37. Retrieved Sept. 20, 2014, from http://ssrn.com/abstract=892341

Salvador R. G., Leiner- Killinger R. (2008). An Analysis of Youth Unemployment in the Euro Area. ECB Occasional Paper No. 89. Retrieved Oct. 4, 2014 from: http://ssrn.com/abstract=1084915

Sileika A., Rupsys V., Gruzevskis B. (2004). Youth Unemployment and Its Reduction Measures. Journal of Business, Economics and Management. Vol. V. No. 3. 119-131.

Sonnet A. (2010). Off to a Good Start? Jobs for Youth. OECD Publishing. Retrieved Sept. 20, 2014, from http://www.oecd.org/employment/ theoecdjobsforyouthreview.htm

The World Development Report 2013. (2013). World Bank. Retrieved Oct. 4, 2014, from http://www.europarl.europa.eu/meetdocs/2009_2014/ documents/empl/dv/wdr_2013_ppt_wdr_2013_ppt_en.pdf

Youth Employment. (2014). Social Agenda, European Commission, No. 36, $1-27$.

Liva Grinevica is a $\mathrm{PhD}$ Student of Regional Economics with the Faculty of Economics and Social Sciences of Latvia University of Agriculture. She received the Master degree in Business Administration (MBA) from the University of Latvia in 2011 and has the qualification of managing director. During studies at the University of Latvia she participated in the exchange study programme in HEC Management School (University of Liege), Liege, Belgium.

Her main research interests are regional development, unemployment, social inclusion, business support programmes.

E-mail: Liva_g2@inbox.1v

Raimonds Kovalevs received the Master degree in Business Administration (MBA) and the qualification of managing director from Turiba University in 2009. He received the Professional Bachelor degree in Social Sciences from Riga Technical University in 2005. Currently he is working in the private banking sector.

His research interests are economics, psychology, business support programmes, finances, banking sector.

E-mail: raimonds.kovalevs@gmail.com 